\title{
Introduction
}

\section{Migration and Differential Labour Market Participation}

\author{
Gina Netto* and Gary Craig**
}

*The Urban Institute, Heriot Watt University

E-mail: G.Netto@hw.ac.uk

**Wilberforce Institute for the study of Slavery and Emancipation, University of Hull

E-mail: G.Craig@hull.ac.uk

Recent major political developments, including Brexit and the US presidential elections, have been strongly associated with public concerns around levels of immigration. Much of this has centred on the role of migrants in the low-skilled sectors of the economy and concerns that they have displaced members of local communities from jobs and depressed wage levels. This is despite compelling evidence that immigrants rarely take jobs from native workers in OECD countries (Constant, 2014) and that in the long run, the wage and employment effects of immigration in the 1990s and in the 2000s were small and always positive for less educated workers of all OECD countries (Docquier et al., 2014). Recent UK specific studies have found that the impact on wages is considered to be relatively small (Dustmann et al., 2013; Nickell and Salaheen, 2015). Notwithstanding this evidence, hostility to migrants and migration more generally has become increasingly overt, as reflected in a substantial rise in 'race' hate crimes before and following the referendum on the UK's membership of the EU in 2016 (Burnett, 2017).

At the time of writing, the government in the UK is negotiating the terms under which the country will leave the European Union, following the triggering of Article 50 of the 2008 Lisbon Treaty. This important juncture makes study of the participation of migrants in the labour market particularly timely, although the upheaval arising from the UK's withdrawal from the EU in 2019 will probably leave many questions unanswered about its impact for many years beyond this time. Understanding the wide range of societal, institutional and individual factors which contribute to the role that migrants play in the labour market will advance current policy and theoretical debates relating to this area. The aim of this themed section is to review the theoretical directions and recurrent themes in the literature, consider the implications of BREXIT and identify areas for future research as well as present key new studies relating to the highly differentiated levels of participation of migrants within the labour market. In so doing, we seek to contribute to theory-building, more informed, nuanced and balanced policy debates and to help shape future research agendas in this area. ${ }^{1}$

While migrants can be found in the highly skilled sectors of the economy as well as low-skilled jobs, the focus in this themed section is on the latter for four main reasons. First, migrants have historically been associated with this sector of the economy in many international contexts, and for a very long period of time. Secondly, it is this aspect of migration which has recently raised heightened political and public concern in both the UK and the US, and is most likely to be the focus of continuing public debate 
and immigration policy. ${ }^{2}$ Thirdly, and relatedly, there is a strong association between lowskilled work and in-work poverty, and while there are formidable barriers to progression to better paid work for all workers, these are especially challenging for ethnic minorities and recent migrants (Netto et al., 2015). Finally, but not least, individuals who are working in the low-skilled sectors of the economy are more likely to be vulnerable to poor treatment, exploitation and forced labour. The issue of labour market exploitation is discussed in two of the contributions to this themed section, reflecting a growing body of literature addressing issues of modern slavery. ${ }^{3}$

The articles in this themed section are all geographically contextualised within countries in Western Europe as destination sites for migrants from within and outwith the EU. Many of the issues raised in the articles relate not only to the expansion of the EU since 2004 and the free movement of people from Accession countries, but also to longstanding trends which have been shaped by economically and politically driven immigration policies of Western European nation states, as well as humanitarian obligations to those fleeing from war and political conflict. The history of migration to European countries has been shaped by a number of factors, not least their colonial pasts, but there is a more or less common set of issues which has emerged in each of them, of which issues related to integration - especially within the labour market - feature prominently (Craig, 2015). Our review of the literature reflects the need to advance inter-disciplinary approaches in theorising migrant participation in the labour market and the value of a historical perspective in examining continuities and discontinuities relating to migrant employment. It also considers some of the implications of Brexit for migrant workers in the UK. Five of the articles in the themed section (those by Heather Rolfe; Tomasso Frattini; Fitzgerald and Smoczyński; Louise Waite; and Flynn's review of resources) are based within the UK; one (by Mullers, Becker and Roos) is focused on the Netherlands and one (by Karen Christensen) adopts a comparative perspective, using the UK and Norway as national case studies of the significantly different welfare regimes for migrant integration.

Collectively, the articles contained in this themed section reveal the highly differentiated levels of migrant integration within the labour market. At a fundamental level, they call attention to the need to acknowledge the sharply different factors which have contributed to forced and economic migration, and the impact of legal status (undocumented migrant, asylum-seeker, refugee, EU migrant, non-EU migrant or third country national) on attachment to the labour market and entitlement to social protection. In doing so, they highlight the need to link enquiry into migratory patterns with an understanding of factors which contribute to the treatment of migrant workers within workplaces and local communities. They also indicate the need for understanding local variation in their participation in the labour market, including demographic factors, levels of regulation, social protection, labour shortages, employer expectations and perceptions of migrants, the (under-) utilisation of the skills, knowledge and experience that migrants bring with them and the aspirations of migrants themselves. Responses to the challenge of integration in the labour market in all European jurisdictions have been very uneven (see for example Craig, 2015).

There are sound economic rationales for identifying the sectors in which migrants work and their contribution to the labour market since they constitute an important component of labour and skills supply. Rolfe's article evidences the growth of key sectors of the UK economy which are linked to migrant presence, explores why employers hire migrant workers and indicates what future immigration policy might look like. Frattini 
examines migrant integration within the labour market, comparing their employment probability, occupational distribution and sectors of occupations relative to those of UKborn natives. His analysis of Labour Force Survey data indicates that new migrants have performed relatively well, obtaining work soon after their arrival, partly as a result of their relative youth and high educational levels. Fitzgerald and Smoczyński's article points to the wider issues relating to the employment of Central and Eastern European migrants in the North of England since 2005, an area which had little history of accommodating migrants. By exploring the perspectives of government, employers and trade unions, they argue that a major attitudinal shift towards these individuals was discernible following the 2008 financial crisis and cuts to local authority funding despite wide-ranging evidence, including from studies funded by government itself, attesting to their value to the UK labour market.

The perspectives of migrants themselves are explored in Christensen's comparative study of care workers in Norway and the UK, reflecting how migratory patterns contribute to changing gender roles within two countries with significantly different welfare regimes. The life course perspective which she employs in her study is compatible with efforts in some national contexts to recognise the skills, knowledge and competencies that migrants bring with them. This is exemplified in Muller, Becker and Roos's study of the effectiveness of the infrastructure for recognition of educational and professional qualifications of nonEU nationals, commonly referred to as third country nationals ( $\mathrm{TCNs}$ ), in the health care sector in the Netherlands. Their study reveals that although the country has a relatively well-developed infrastructure for the recognition of such qualifications, TCNs often find that their qualifications are not considered equivalent to relevant Dutch qualifications, a pattern again common in most European states. Further, processes relating to the accreditation and recognition of prior learning are flawed, limiting efforts to address serious labour shortages in the country and the contribution that these individuals could make to the health care sector.

In contrast to Muller et al.'s study of issues arising from a highly regulated sector within the Netherlands, Waite's study focuses on the very difficult conditions of employment in unregulated sectors of the economy, where undocumented migrants and asylumseekers are forced illegally to find work. Waite argues that these individuals form a 'hyper-exploitable' pool of unprotected workers due to the nature of their circumstances, which largely constitutes for-cash labouring in low-paid labour market sectors, and their situation is likely to continue to worsen within the context of an increasing hardening of attitudes towards some categories of migrants. Following this article, Flynn's contribution of key networks and sources of information and support relating to the employment of migrant workers represents a valuable resource for academics and activists alike.

In addition to discussing empirical and highly policy-relevant issues relating to migration and the labour market, the articles make rich contributions to theory building. Rolfe's article finds little evidence in support of the concepts of 'ethnic hiring' or 'ethnic queues' (Scott, 2013; McCollum and Findlay, 2015), which suggest that groups are ordered ethnically according to employers' preferences based on factors such as 'work ethic'. Instead, the study reveals that it is migrant flexibility to respond to labour market demands and to either increases or decreases in their hours of work that gives them an edge over British workers and makes them seemingly indispensable to employers. The articles of Frattini and that of Christensen enrich understanding of the phenomenon of 'occupational downgrading' among migrants where individuals take on jobs for which they are 
over-qualified. The former reveals that downgrading is higher for more recent arrival cohorts, who are more likely to be working in unskilled occupations despite their higher levels of education, reinforcing the importance of understanding the influence of externalities that impact on migrant employment over time. The latter reveals the complex interaction between country-specific factors, including the role of the state in shifting responsibility on to private households in the care sector and the intersectionality of migrant identity and gender on changing orientations to work.

Muller and colleagues' study of the infrastructure, which has been established in the Netherlands to recognise the skills, knowledge and competencies that third country nationals have acquired in their country of origin, reveals the tensions noted by Zanfrini (2015) between immigration policies, which are driven by the need to meet labour shortages and ensure political viability, and human rights-based motivations to promote solidarity and equal opportunities. The study reveals insights relating to the 'normal' functioning of institutions, which tend unintentionally to produce discriminatory processes and reproduce existing patterns of inequality within the labour market, despite the existence of inclusionary policies. The role of the state in marginalising some groups of migrants is also clearly illlustrated in Waite's study which establishes the concept of 'hyper-precarity' to refer to the extremely difficult position of asylum-seekers who have been refused the right to work through increasingly restrictive immigration legislation.

When we planned this themed collection of articles, before the outcome of the EU Referendum in June 2016, our hope was that it would help to dispel some of the myths which circulated before and during the Referendum about the drain that migrants placed on the UK economy (and that of other EU countries). Quite the reverse seems to be substantially the case. There are some very serious questions to be answered about the contribution to and impact of migration on national labour markets. Figures recently released by the UK-based Office for National Statistics in 2016 revealed that 11 per cent of the workforce was made up of non-UK nationals. Migrants are currently heavily represented not only in the hospitality, retail and restaurant sectors, but also in key public services, including public administration, education and the health service - often in roles for which they are over-qualified. It is far from clear how their current contribution to the labour market will either be substituted or complemented. Further, issues relating to migrant employment raise other serious concerns, which extend beyond their contribution to the economy, as we will argue in the review following this introduction. At the time of writing, the need for public policy and debate to be underpinned by a more informed understanding of the relationships between migration and labour markets - as communicated through the kind of dispassionate and evidence-based analysis provided by this collection of articles - seems ever-more important.

\section{Notes}

1 Ironically, of course, one impact of the UK withdrawal is that researchers in the UK may have to think of more creative ways to work collaboratively with mainland European colleagues because funding streams may no longer be open to them.

2 See, for instance, Balch (2017), Craig (2015), Dwyer et al. (2011) and Waite et al. (2015).

3 See, for example, Skrivankova (2010) and Waite et al. (2015). 


\section{References}

Balch, A. R. (2017) Immigration and the State, Basingstoke: Palgrave Macmillan.

Burnett, J. (2017) 'Racial violence and the Brexit state', Race and Class, 58, 4, 85-97.

Constant, A. (2014) Do Migrants Take the Jobs of Native Workers? IZA World of Labour, https://wol.iza.org/uploads/articles/10/pdfs/do-migrants-take-the-jobs-of-native-workers.pdf?v=1 [accessed 09.05.2017].

Craig, G. (2015) Migration and Integration: A Local and Experiential Perspective, Working Paper 7-2015, Birmingham: IRIS, University of Birmingham.

Docquier, F., Çağlar, O. and Peri, G. (2014) 'The labour market effects of immigration and emigration in OECD countries', Economic Journal, Royal Economic Society, 124, 579, 1106-45.

Dustmann, C., Frattini, T. and Preston, I. P. (2013) 'The effect of immigration along the distribution of wages', Review of Economic Studies, 80, 1, 145-73.

Dwyer, P., Lewis, H., Scullion, L. and Waite, L. (2011) Forced Labour and Immigration Policy: Status Matters?, York: Joseph Rowntree Foundation.

McCollum, D. and Findlay, A. (2015) "Flexible" workers for "flexible" jobs? The labour market function of A8 migrant labour in the UK', Work Employment and Society, 29, 3, 427-43.

Netto, G., Hudson, M., Noon, M., de Lima, P. and Kamenou-Aigbekaen, N. (2015) 'Migration, ethnicity and progression from low-paid work: implications for skills policy', Social Policy and Society, 14, 4, $509-22$.

Nickell, S. and Salaheen, J. (2015) 'The impact of immigration on occupational wages: evidence from Britain', Staff Working Paper No. 574, Bank of England, London.

Scott, S. (2013) 'Migrant-local hiring queues in the UK Food industry', Population, Space and Place, 19, $5,459-71$.

Skrivankova, K. (2010) Between Decent Work and Forced Labour: Examining the Continuum of Exploitation, York: Joseph Rowntree Foundation.

Waite, L., Craig, G., Lewis, H. and Skrivankova, K. (eds.) (2015) Vulnerability, Exploitation and Migrants, Basingstoke: Palgrave.

Zanfrini, L. (2015) The Diversity Value - How to Reinvent the European Approach to Immigration, Maidenhead, UK: McGraw-Hill Education. 